\title{
HOME AUTOMATION SYSTEM DENGAN MENGGUNAKAN RASPBERRY PI 4
}

\author{
Trio Ade Mulyanto ${ }^{1}$, Mukhtar Habiby², Kusnadi ${ }^{3}$, Rinaldi Adam ${ }^{4}$ \\ Universitas Catur Insan Cendekia \\ Jl. Kesambi No. 202, Cirebon \\ e-mail: trioademulyanto@gmail.com¹, abyaby.ay@gmail.com², kusnadi@cic.ac.id ${ }^{3}$, \\ rinaldi.adam@cic.ac.id ${ }^{4}$
}

\begin{abstract}
ABSTRAK
Home automation merupakan salah satu kemajuan teknologi dan komunikasi dengan otomasi kontrol terhadap rumah. Dengan metode ini, perangkat-perangkat elektronik rumah dapat di kontrol mengunakan sistem kendali jarak jauh tanpa harus menyetuh perangkat elektronik yang ada di rumah. Raspberry Pi digunakan sebagai pemroses untuk menciptakan sebuah sistem. Raspberry Pi merupakan mini computer yang fungsi-fungsi dasarnya sama seperti sebuah personal komputer biasa dengan ukuran sebesar kartu kredit. Raspberry Pi dapat mengontrol perangkat-perangkat elektronik yang berada di rumah dengan memanfaatkan fasilitas GPIO (General Purpose Input Output). Perangkat elektronika yang dapat di control meliputi lampu, kipas angin, suhu ruangan, kamera pengintai dan masih banyak lagi.

Perancangan sistem meliputi perancangan alat untuk sistem kontrol arus di mana mengunakan Raspberry Pi untuk mengontrol 6 buah lampu, kipas sensor suhu, sensor motion dan 1 buah adaptor atau kontak saklar dengan memanfaatkan Relay 8 chanel sebagai penghubung dan juga sebagai saklar on / off. Tahap implementasi dilakukan dengan mengambungkan perangkat lunak dan perangkat keras untuk menghasilkan sistem control dengan menghubungkan web server sebagai media interface dan yang terakhir uji coba sistem yang di bangun. Sistem yang di bangun akan menjadi sistem kontrol perangkat elektronik rumah dengan implementasinya menyalakan dan mematikan lampu, mengecek suhu ruangan ,menyalakan kipas dan monitoring keadaan rumah dengaan memanfaatkan web server yang di tanam di dalam raspberry pi sebagai media interface user berupa web yang akan di akses user mengunakan smartphone atau komputer. Dengan ini sistem yang di bangun akan sangat membantu pengguna dalam melakukan pengontrolan perangkat elektronik rumah dimanapun pengguna berada dan menghemat daya listrik.
\end{abstract}

Kata Kunci : Home Automation, Smarthome, Raspberry Pi.

\begin{abstract}
Home automation is one of the advances in technology and communication with control automation of the home. With this method, home electronic devices can be controlled using a remote control system without having to touch any electronic devices in the house. Raspberry Pi is used as a processor to create a system. Raspberry $P i$ is a mini computer whose basic functions are the same as an ordinary personal computer with the size of a credit card. Raspberry Pi can control electronic devices at home by utilizing the GPIO (General Purpose Input Output) facility. Electronic devices that can be controlled include lights, fans, room temperature, surveillance cameras and much more.

System design includes designing a tool for a current control system where using the Raspberry $\mathrm{Pi}$ to control 5 lights and 1 adapter or switch contact by utilizing an 8 channel relay as a connector and also as an on / off switch. The implementation stage is carried out by connecting software and hardware to produce a control system by connecting the web server as a media interface, and finally testing the system being built. The system that is built will be a home electronic device control system with the implementation
\end{abstract}


of turning on and off the lights, checking the room temperature, turning on the fan and monitoring the state of the house by utilizing a web server planted in raspberry pi as a media user interface in the form of a web that will be accessed by users using a smartphone or computer. With this the system that is built will greatly assist users in controlling home electronic devices wherever the user is and save electrical power.

\section{Keywords: Home Automation, Smarthome, Raspberry Pi.}

\section{Pendahuluan}

Di era modern seperti sekarang ini perkembangan dalam bidang teknologi telah mengalami perubahan yang cukup pesat. Kini hampir semua kegiatan atau aktifitas sehari-hari telah memanfaatkan kemajuan teknologi sebagai upaya untuk mempermudah serta membantu agar lebih efektif dan efisien. Hal ini dapat membuat segala sesuatu yang sulit menjadi lebih mudah, praktis serta tidak memakan waktu yang lama.

Salah satu perkembangan teknologi yang sedang berkembang saat ini yaitu Raspberry Pi yang merupakan sebuah komputer kecil berukuran hampir seperti kartu kredit. Meskipun memiliki ukuran yang kecil namun Raspberry Pi dilengkapi dengan prosesor, RAM dan port hardware yang khas sehingga dapat berfungsi seperti komputer pada umunya.

Dengan pesat nya perkembangan Internet of Thinks, maka internet pun dapat di manfaatkan untuk keperluan yang mendukung pembelajaran, salah satunya adalah di gunakan sebagai sistem control otomatis jarak jauh mengunakan microcontroller. Penerapan dari internet of thinks ini berupa pengendalian perangkat elektronik rumah mengunakan microcontroller Rasberry pi 4 atau yang kita kenal sebagai Home automation atau Smart Home.

Dari penjelasan diatas maka kami mengusulkan sebuah penelitian yang berjudul "Home Automation System Dengan Menggunakan Raspberry Pi 4". Inovasi ini diharapkan dapat membantu untuk memantau keadaan rumah ketika pemilik sedang berada diluar.

\subsection{Identifikasi Masalah}

Berdasarkan latar belakang yang telah diuraikan diatas maka dapat dirumuskan identifikasi masalah sebagai berikut :

1. Bagaimana alur pembuatan Hardware dan software untuk smarthome mengunakan Rapsberry Pi4 berbasis web?

2. Bagaimana pengaplikasian smarthome mengunakan Raspberry Pi 4 ?

\subsection{Tujuan}

Berdasarkan dengan permasalahan yang ada maka tujuan dari pembuatan sistem ini adalah sebagai berikut :

1. Mampu merancang bagun smarthome berbasis internet mengunakan Raspberry Pi 4

2. Membuat sistem yang mampu memberikan informasi untuk keamanan dan kemudahan

\subsection{Metodologi Penelitian}

Prosedur penelitian yang digunakan dalam penelitian ini adalah RAD (Rapid Aplication Development). Rapid Aplication Development (RAD) adalah sebuah proses perkembangan perangkat lunak sekuensial linier yang menekankan siklus perkembangan dalam waktu yang singkat.

\section{KAJIAN PUSTAKA}

\subsection{Home Automation}

Home Automation atau biasa juga disebut Smarthome adalah suatu rumah yang dilengkapi dengan sistem untuk mengintegrasikan dan mengontrol alat-alat elektronik yg ada dirumah, misalnya Lampu, TV, Home Theater, CCTV, Alarm, Kipas angin, Door Lock, Motion Sensor, dan masih banyak lagi.

\subsection{Sistem}

Sistem adalah suatu kesatuan, baik obyek nyata atau abstrak yang terdiri dari berbagai komponen atau unsur yang saling berkaitan, saling tergantung, saling mendukung, dan secara keseluruhan bersatu dalam satu kesatuan untuk mencapai tujuan tertentu secara efektif dan efisien. 


\subsection{Home Automation System}

Home Automation (Smart Home System) adalah sistem yang digunakan untuk mengintegrasikan berbagai sistem yang umumnya terdapat dalam suatu rumah (bangunan). Dengan terintegrasinya berbagai sistem ini diharapkan dapat meningkatkan:

a. Kenyamanan: tingkat penerangan, suhu, kelembaban yang optimum

b. Keamanan: proteksi terhadap akses, alarm system, dan monitoring keadaan.

c. Kemudahan: mengontrol berbagai sistem dimanapun dan kapanpun.

d. Efisiensi: menggunakan resource/energi sesuai dengan kebutuhan.

\subsection{Metodologi Rapid Application Development (RAD)}

RAD adalah penggabungan beberapa metode atau teknik terstruktur. RAD menggunakan metode prototyping dan teknik terstruktur lainnya untuk menentukan kebutuhan user dan perancangan sistem informasiselain itu RAD menekankan siklus perkembangan dalam waktu yang singkat (60 sampai 90 hari) dengan pendekatan konstruksi berbasis komponen. Tahapan-tahapan Model RAD :

1. Bussiness Modelling

Fase ini untuk mencari aliran informasi seperti: informasi mengendalikan proses bisnis, di mana informasi digunakan, siapa yang memprosenya, dan informasi apa yang dimunculkan.

2. Testing and Turnover

Karena menggunakan kembali komponen yang telah ada, maka akan mengurangi waktu pengujian.

Tetapi komponen baru harus diuji dan semua interface harus dilatih secara penuh..

3. Aplication Generation

Selain menggunakan bahasa pemrograman generasi ketiga, RAD juga memakai komponen program yang telah ada atau menciptakan komponen yang bisa dipakai lagi. Alat-alat baantu bisa dipakai untuk memfasilitasi konstruksi perangkat lunak.

4. Process Modelling

Aliran informasi pada fase data modelling ditransformasikan untuk mendapatkan aliran informasi yang diperlukan pada implementasi fungsi bisnis. Pemrosesan diciptakan untuk menambah, memodifikasi, menghapus, atu mendapatkan kembali objek data tertentu.

5. Data Modelling

Fase ini menjelaskan objek data yang dibutuhkan dalam proyek. Karakteristik (atribut) masingmasing data diidentifikassikan dan hubungan antar objek didefinisikan.

\subsection{Raspberry Pi}

Raspberry $\mathrm{Pi}$, sering disingkat dengan nama Raspi, adalah komputer papan tunggal (single-board circuit; SBC) yang seukuran dengan kartu kredit yang dapat digunakan untuk menjalankan program perkantoran, permainan komputer, dan sebagai pemutar media hingga video beresousi tinggi. Raspberry Pi dikembangkan oleh yayasan nirlaba, Rasberry Pi Foundation, yang digawangi sejumlah pengembang dan ahli komputer dari Universitas Cambridge, Inggris.

Ide dibalik Raspberry Pi diawali dari keinginan untuk mencetak pemrogram generasi baru. Seperti disebutkan dalam situs resmi Raspberry Pi Foundation, waktu itu Eben Upton, Rob Mullins, Jack Lang, dan Alan Mycroft, dari Laboratorium Komputer Universitas Cambridge memiliki kekhawatiran melihat kian turunnya keahlian dan jumlah siswa yang hendak belajar ilmu komputer. Mereka lantas mendirikan yayasan Raspberry Pi bersama dengan Pete Lomas dan David Braben pada 2009. Tiga tahun kemudian, Raspberry Pi Model B memasuki produksi massal. Dalam peluncuran pertamanya pada akhir Febuari 2012 dalam beberapa jam saja sudah terjual 100.000 unit. Pada bulan Februari 2016, Raspberry Pi Foundation mengumumkan bahwa mereka telah menjual 8 juta perangkat Raspi, sehingga menjadikannya sebagai perangkat paling laris di Inggris. 


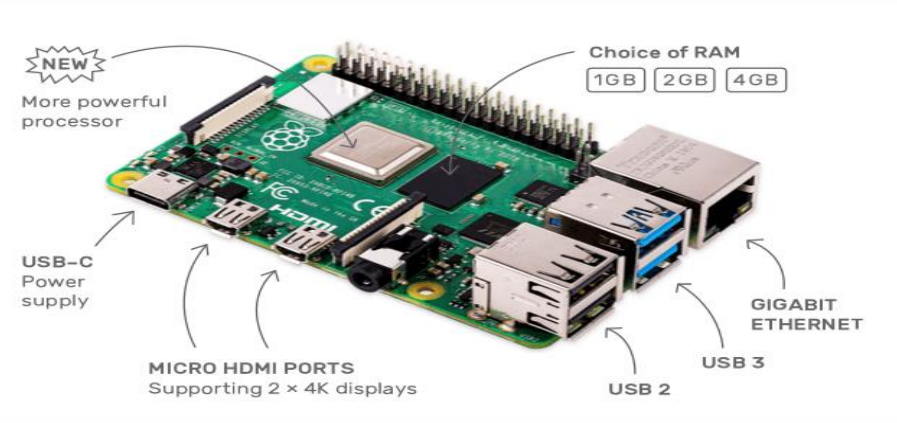

Gambar 1. Raspberry Pi

\section{METODE PENELITIAN}

\subsection{M!etode}

\subsection{Analisa Kebutuhan Perangkat Lunak}

Adapun spesifikasi kebutuhan perangkat lunak yang dibutuhkan dalam pembuatan home automation system penggunaanya antara lain:

\section{Table 1. Analisa Kebutuhan Perangkat Lunak}

\begin{tabular}{|l|l|l|}
\hline \multicolumn{2}{|l|}{ Spesifikasi Pembuatan } & \multicolumn{1}{c|}{ Deksripsi } \\
\hline No. & \multicolumn{1}{|c|}{ Perangkat Lunak } & Microsoft Windows 10 64 bit \\
\hline 1 & Sistem Operasi Komputer & 1. Raspbian \\
\hline 2 & Aplikasi Editor & 2. Phyton \\
\hline & & 3. MobaXtream \\
\hline & & 4. Notepad++ \\
\hline & & 5. Fritzing \\
\hline & & 6. SSH (Secure Shell) \\
\hline
\end{tabular}

\subsection{Perancangan Sistem}

Perancangan sistem untuk perangkat IoT sistem monitoring dan kontrol otomatis yang penulis buat dalam projek ini menggunakan diagram blok dan flowchart:

\subsubsection{Perancangan System Home Automation}

Perancangan sistem home automation dilakukan dengan menggunakan desain mekanik. Raspberry Pi mengatur secara langsung berbagai macam kegiatan yang akan dilakukan oleh user seperti, menghidupkan / mematikan lampu dan mengatur suhu AC / Kipas. Untuk melakukan kegiatan tersebut diperlukan Relay sebagai perantara untuk menghubungkan antara Raspberry dengan lampu dan juga sensor suhu DHT22. 


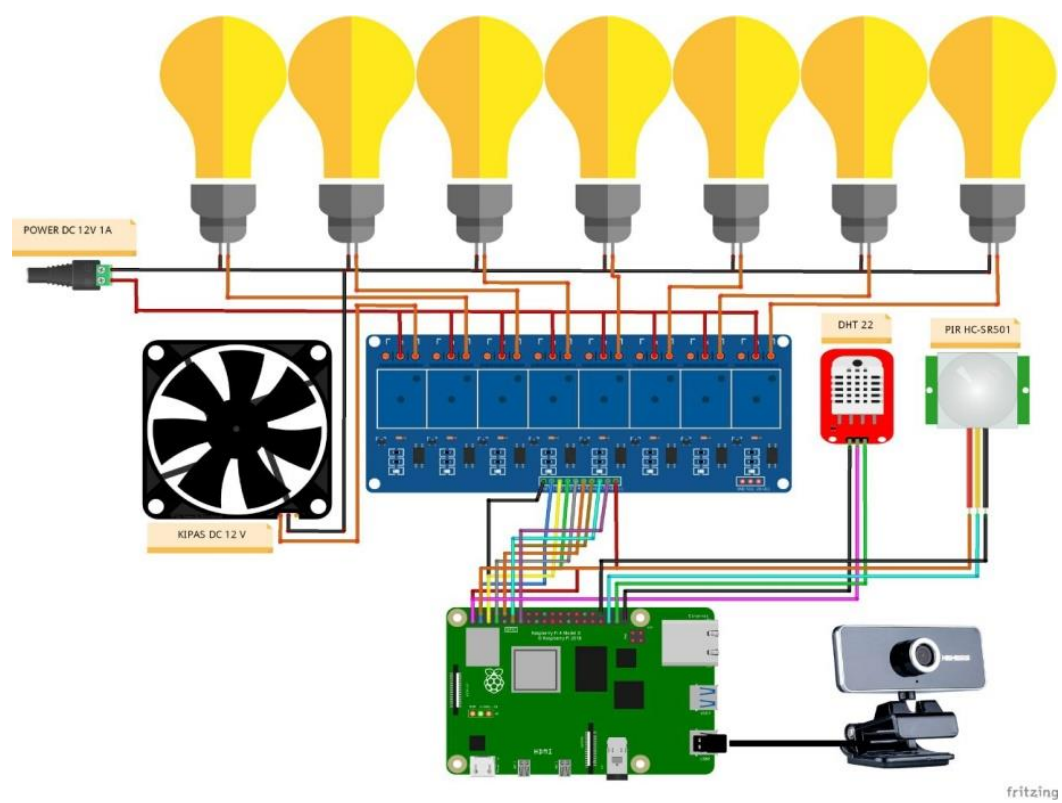

Gambar 2. Perancangan Sistem Home Automation

\subsubsection{Diagram Blok Perancangan Perangkat Keras}

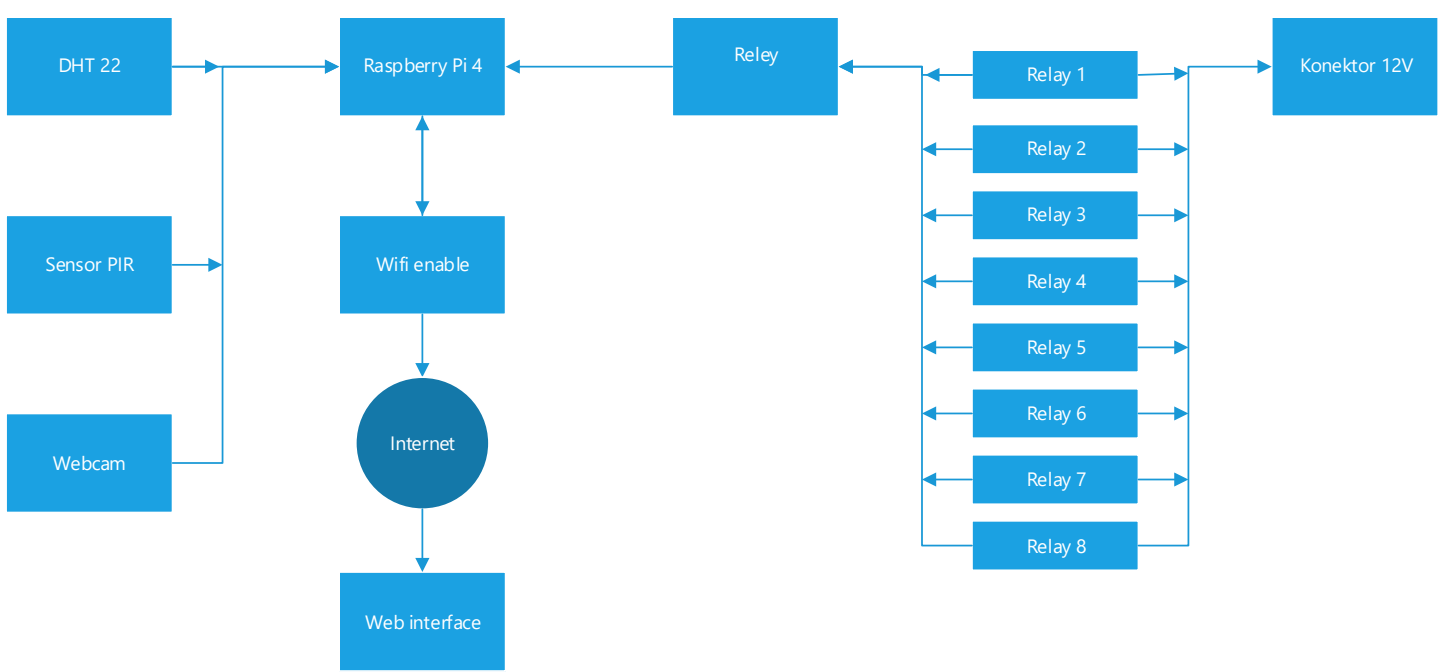

Gambar 3. Diagram Blok Perancangan Sistem Home Automation

Diagram blok diatas menggambarkan cara kerja antar perangkat dalam sistem monitoring home automation dengan penjelasan sebagai berikut :

1. Adaptor merupakan perangkat yang digunakan untuk memberi daya listrik pada Raspberry Pi 4

2. Laptop atau PC merupakan perangkat untuk melihat hasil tampilan dari webcam melalui tampilan web browser

3. Router merupakan perangkat yang menghubungkan Raspberry $\mathrm{Pi} 4$ untuk mengirim sinyal internet kepada Raspberry Pi 4 supaya dapat diakses di internet

4. Relay merupakan sebuah perangkat penghubung yang dapat menghubungkan antara Raspberry Pi 4 dengan lampu dan kipas 
5. Lampu merupakan sebuah komponen Output

6. Kipas merupakan sebuah komponen Output

7. Webcam atau Web Camera merupakan sebuah perangkat untuk memonitoring ruangan seperti kamar, garasi dan ruang keluarga

8. Sensor DHT22 atau AM2302 merupakan sebuah perangkat yang digunakan untuk mendeteksi suhu pada ruangan

9. Sensor Motion merupakan sebuah perangkat yang digunakan untuk mendeteksi tingkat radiasi inframerah pada kamar mandi sehingga ketika seseorang memasuki kamar mandi maka lampu yang ada dikamar mandi otomatis menyala

10. Chrome merupakan sebuah perangkat lunak yang digunakan untuk melihat hasil webcam, suhu ruangan, tombol On/Off untuk meyalakan serta mematikan lampu dan kipas pada tampilan web

11. Raspberry Pi 4 merupakan alat utama sebagai jembatan penghubung Web browser, relay dan webcam

\subsubsection{Flowchart Cara Kerja Sistem}

Berdasarkan dari perancangan sistem monitoring dan kontrol otomatis di atas, maka dibuatlah rancangan sistem. Dalam merancang suatu sistem penulis terlebih dahulu membuat flowchart sebagai panduan untuk membuat sistem. Seperti diketahui, dalam merancang sebuah program harus diperhatikan aturan logika yang benar. Jika logika dalam satu program tidak benar, tentu akan menyebabkan adanya kesalahan dari hasil keluaran program tersebut dan tidak sesuai hasil keluaran yang diinginkan. Untuk membantu melacak kebenaran logika sebuah program dan juga dapat membantu memahami sebuah persoalan seringkali diperlukan suatu alat yang digunakan untuk merancang sebuah sistem, salah satunya flowchart. Hardware :

Berikut adalah Flowchart cara kerja sistem diantaranya Flowchart cara kerja Software dan

\subsubsection{Flowchart Cara Kerja Software dan Hardware}

Flowchart cara kerja software ini merupakan rancangan cara kerja software yang terdapat pada sistem home automatioan. Berikut adalah flowchart cara kerja software yang terdapat dalam gambar 3 .

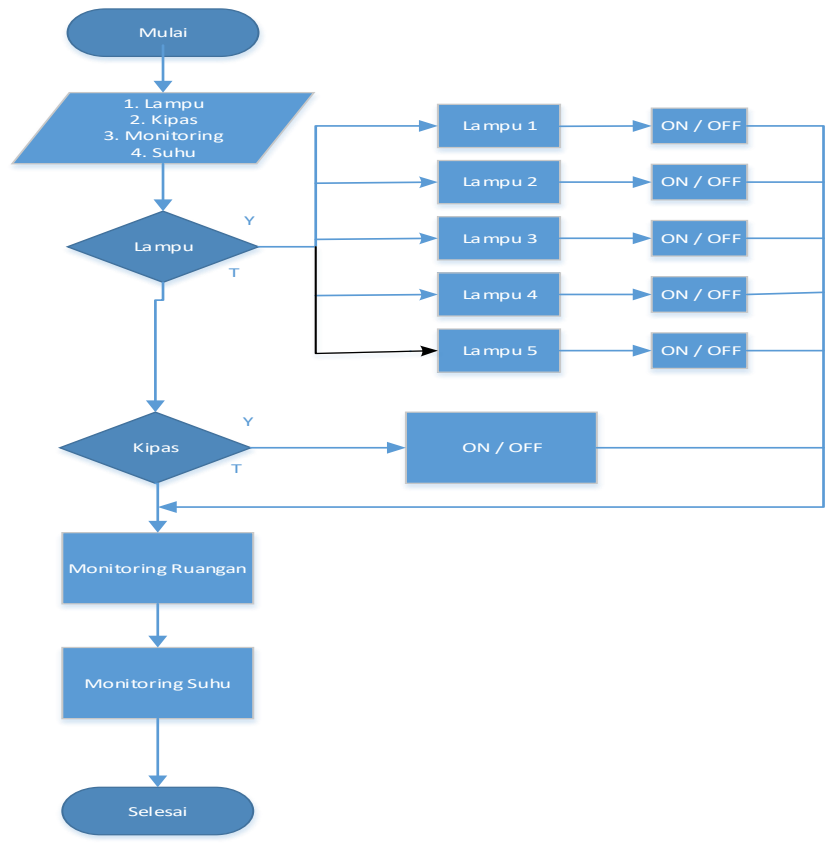

Gambar 4. Flowchart Cara Kerja Software

Berikut adalah Flowchart Cara Kerja Hardware yang terdapat pada gambar 5. 


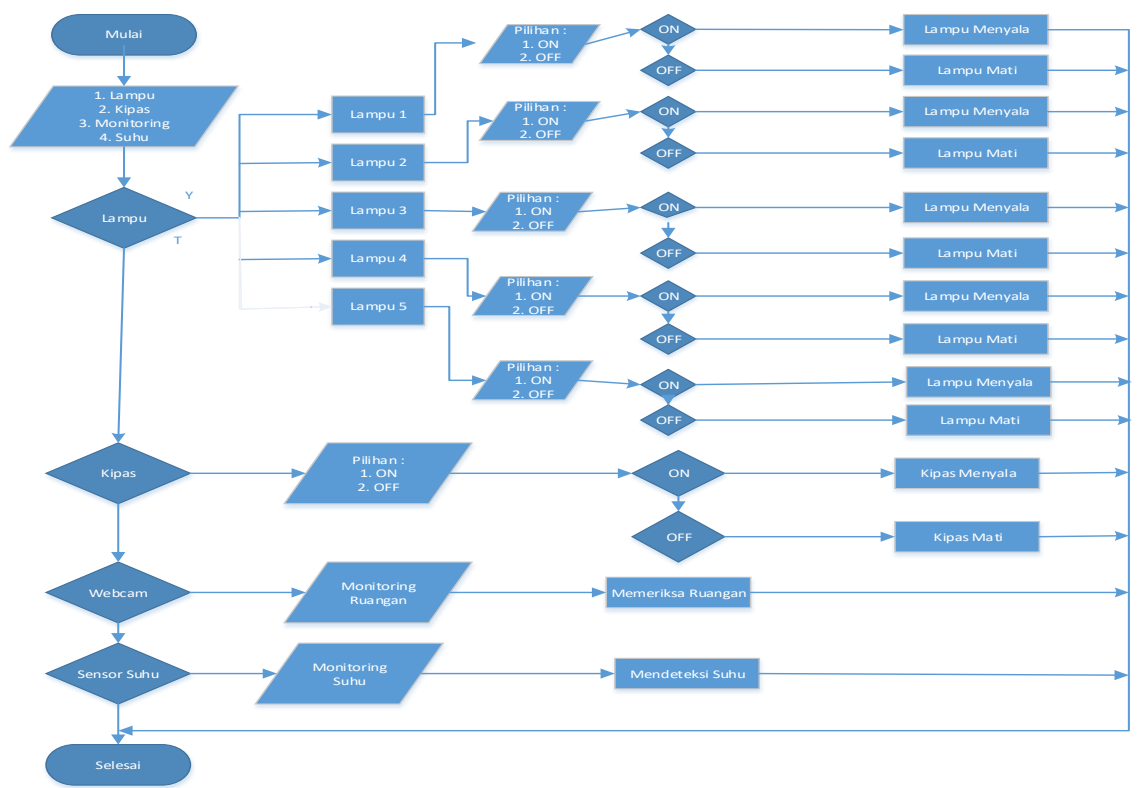

Gambar 5. Flowchart Cara Kerja Hardware

\subsection{Perancangan Web}

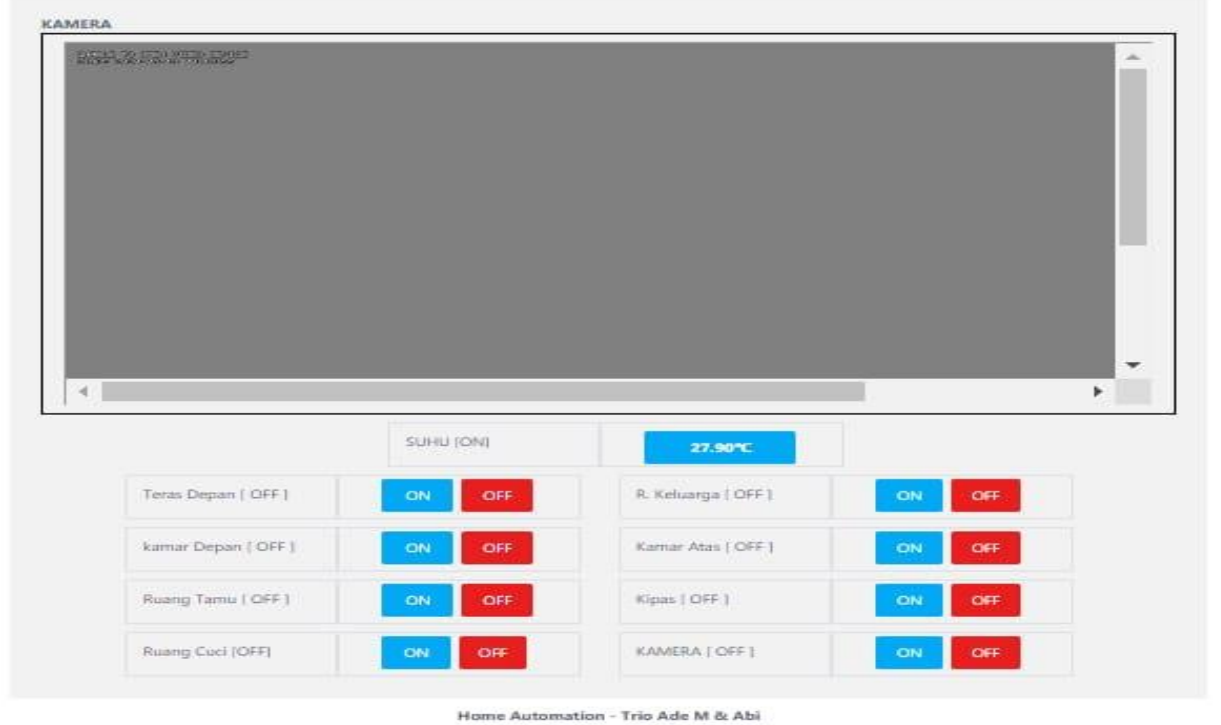

Gambar 6. Perancangan Tampilan Web

Gambar diatas menjelaskan perancangan web pada sistem Home Automation dengan menggunakan Raspberry Pi 4. Perancangan tersebut akan digunakan sebagai media untuk user dalam mengontrol sistem ini seperti menekan tombol On / Off untuk mengaktifkan dan juga menonaktifkan sistem. Dalam hal ini, user dapat dengan mudah untuk mengontrol keadaan rumahnya ketika sedang berada diluar sehingga user akan memastikan sendiri apakah rumah yang di tinggalkannya dalam keadaan aman atau tidak.

Cara kerja sistem ini dimulai dengan Raspberry Pi yang tersambung dengan koneksi internet lalu user membuka web tersebut dan akan muncul tampilan seperti tampilan perancangan web diatas. Setelah 
muncul tampilan tersebut, user dapat memilih On untuk mengaktifkan atau memilih Off untuk menonaktifikan. Dalam tampilan seperti ini, user dapat dengan mudah dalam mengontrol sistem Home Automation sehingga dapat selalu memantau dan memastikan keamanan rumahnya.

Berikut adalah rancangan tampilan web untuk setiap komponen fitur yang terdapat dalam sistem home automation diantaranya adalah sebagai berikut :

1. Rancangan tampilan web untuk fitur suhu

\section{SUHU IOTI \\ $2 \pi \cos$}

Penjelasan :

Gambar 7. Rancangan Tampilan Web - Fitur Suhu

Rancangan tampilan web dalam sistem Home Automation untuk fitur suhu dapat digunakan untuk mengatur suhu dalam suatu ruangan yang telah dipasangkan sensor suhu dan telah dihubungkan dengan Raspberry yang terhubung dengan jaringan internet. User dapat mengatur suhu ruangan sesuai dengan yang diinginkan hanya dengan mengklik tombol yang tersedia dan mengaturnya sesuai keinginan maupun kebutuhan user.

2. Rancangan tampilan web untuk fitur Lampu Teras Depan

Teras Dernan | OFF |

Gambar 8. Rancangan Tampilan Web - Teras Depan

Penjelasan :

Rancangan tampilan web dalam sistem Home Automation untuk fitur lampu teras depan dapat digunakan untuk menyalakan / mematikan lampu. User dapat membuka web dan memilih tombol On untuk menyalakan lampu teras depan dan memilih tombol Off untuk mematikan lampu teras depan.

3. Rancangan tampilan web untuk fitur Lampu Kamar Depan

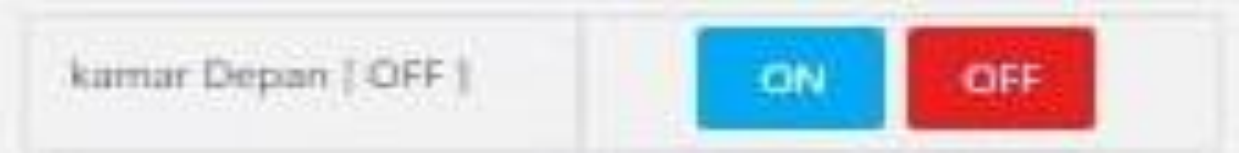

Penjelasan :

\section{Gambar 9. Rancangan Tampilan Web-Kamar Depan}

Rancangan tampilan web dalam sistem Home Automation untuk fitur Kamar Depan dapat digunakan untuk menyalakan / mematikan lampu. User dapat membuka web dan memilih tombol On untuk menyalakan lampu kamar depan dan memilih tombol Off untuk mematikan lampu kamar depan.

4. Rancangan tampilan web untuk fitur Lampu Ruang Tamu
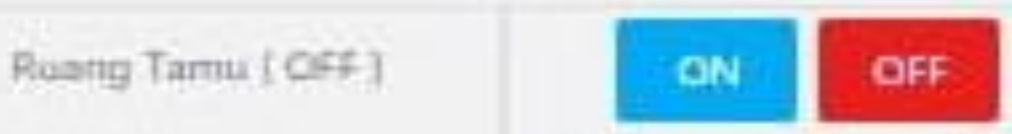

Gambar 10. Rancangan Tampilan Web-Ruang Tamu

Penjelasan :

Rancangan tampilan web dalam sistem Home Automation untuk lampu fitur ruang tamu dapat digunakan untuk menyalakan / mematikan lampu. User dapat membuka web dan memilih tombol On untuk menyalakan lampu ruang tamu dan memilih tombol Off untuk mematikan lampu ruang tamu.

5. Rancangan tampilan web untuk fitur Lampu Ruang Cuci

JURNAL DIGIT Vol. 11, No.1 Mei 2021, pp.60 73 


\section{Ruang CACI FOFFI}

Penjelasan :

\section{Gambar 11. Rancangan Tampilan Web - Fitur Ruang Cuci}

Rancangan tampilan web dalam sistem Home Automation untuk fitur lampu ruang cuci dapat digunakan untuk menyalakan / mematikan lampu. User dapat membuka web dan memilih tombol On untuk menyalakan lampu ruang cuci dan memilih tombol Off untuk mematikan lampu ruang cuci.

6. Rancangan tampilan web untuk fitur Lampu Ruang Keluarga
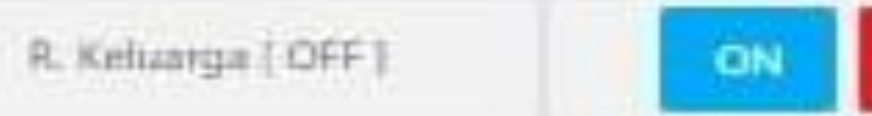

\section{GF}

\section{Gambar 12. Rancangan Tampilan Web - Fitur Ruang Keluarga}

Rancangan tampilan web dalam sistem Home Automation untuk fitur ruang keluarga dapat digunakan untuk menyalakan / mematikan lampu. User dapat membuka web dan memilih tombol On untuk menyalakan lampu ruang keluarga dan memilih tombol Off untuk mematikan lampu ruang keluarga.

7. Rancangan tampilan web untuk fitur Menyalakan Kipas

\section{Karnar Atas | OFF-}
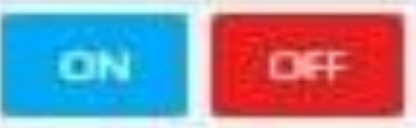

Gambar 13. Rancangan Tampilan Web - Fitur Kamar Atas

Rancangan tampilan web dalam sistem Home Automation untuk fitur kamar atas dapat digunakan untuk menyalakan / mematikan lampu. User dapat membuka web dan memilih tombol On untuk menyalakan lampu kamar atas dan memilih tombol Off untuk mematikan lampu kamar atas.

8. Rancangan tampilan web untuk fitur Menyalakan Kipas
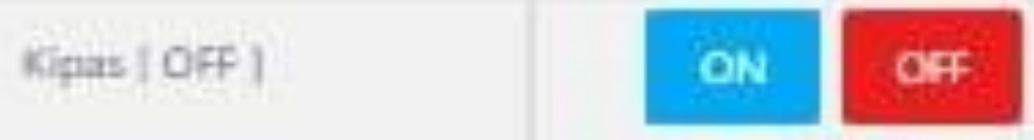

Gambar 14. Rancangan Tampilan Web - Kipas

Rancangan tampilan web dalam sistem Home Automation untuk fitur kipas dapat digunakan untuk menyalakan / mematikan lampu. User dapat membuka web dan memilih tombol On untuk menyalakan kipas dan memilih tombol Off untuk mematikan kipas.

9. Rancangan tampilan web untuk fitur Kamera
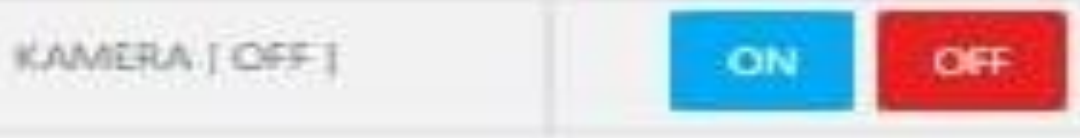

Gambar 15. Rancangan Tampilan Web - Fitur Pengatur Kamera 
Rancangan tampilan web dalam sistem Home Automation untuk fitur pengatur kamera dapat digunakan untuk menyalakan / mematikan lampu. User dapat membuka web dan memilih tombol On untuk menyalakan kamera dan memilih tombol Off untuk mematikan kamera.

8. Rancangan tampilan web untuk fitur kamera (Webcam)

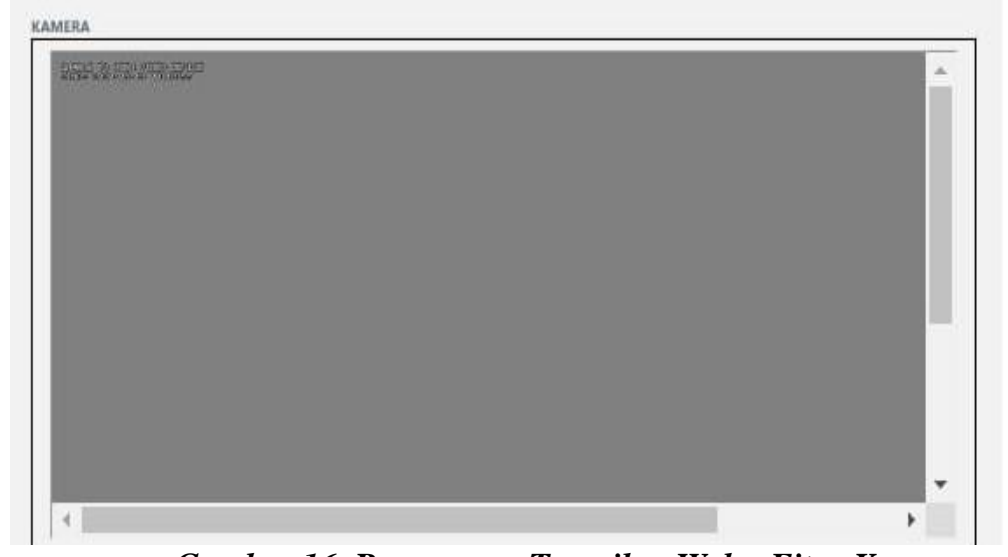

Penjelasan :

Gambar 16. Rancangan Tampilan Web - Fitur Kamera

Rancangan tampilan web untuk fitur kamera dalam sistem Home Automation berfungsi untuk membantu user dalam melakukan monitoring ruangan. Untuk mengaktifkan fitur ini, user dapat mengklik tombol On untuk memulai melakukan monitoring dan memilih tombol Off untuk menonaktifkan kamera.

\section{HASIL DAN PEMBAHASAN}

\subsection{Implementasi Web}

Aplikasi Home Hutomation pengendali peralatan elektronik rumah tangga ini mengunakan interface berbasis web dengan software yang di gunakan adalah PHP 7.3, interface di gunakan sebagai penghubung antara penguna dengan GPIO sebagai pengontrol lampu, kipas , monitoring suhu,dan memonitoring keadaan rumah.

Di dalam file index.html di gfunakan untuk membuat template atau halaman pada web yang berupa tombol sebagai saklar untuk simulasi lampu, kipas, suhu ruangan dan kamera. Dan juga di gunakan untuk membaca GPIO yang menghubungkan antara penguna dengan lampu, kipas, suhu ruangan, dan monitoring keadaan ruangan yang tertuju pada library Wiring pi.

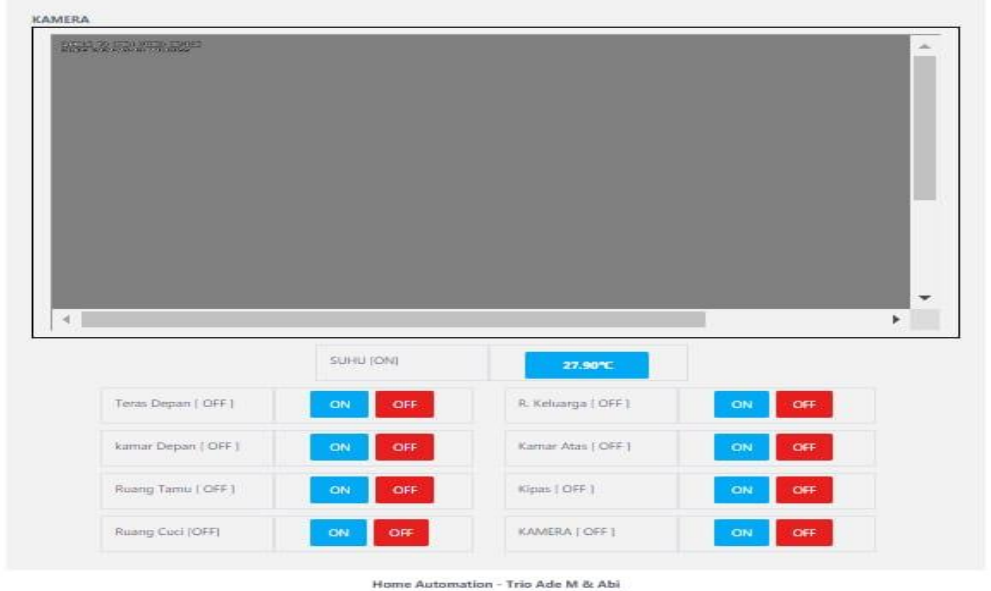

Gambar 17. Web Kontrol

Pada aksi tombol dalam sebuah web akan mengirimkan input pada database dengan coding seperti gambar berikut. 


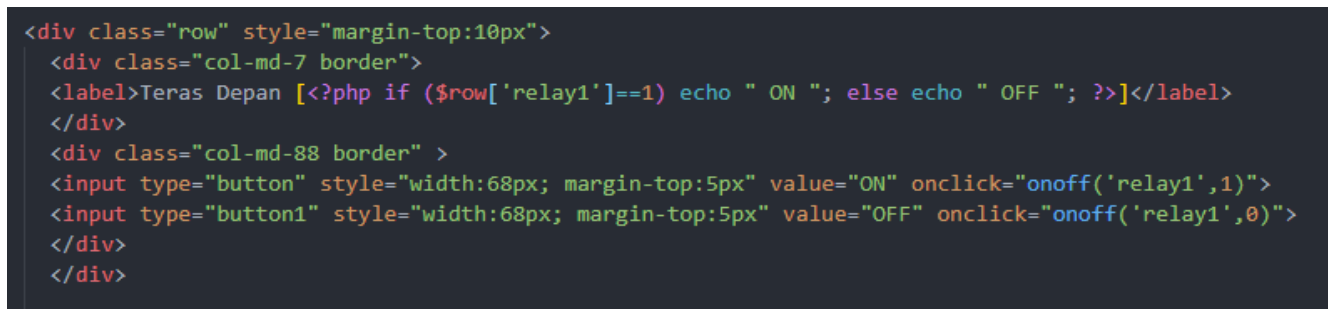

\section{Gambar 18. Coding Php}

Dari gambar coding di atas maka nilai yg akan di kirimkan pada data base akan bernilai 1 / 0 atau true / false yang mana data tersebut akan di gunakan sebagai perintah untuk menghidupkan atau mematikan relay dengan nilai yang terdapat pada tampilan database berikut.

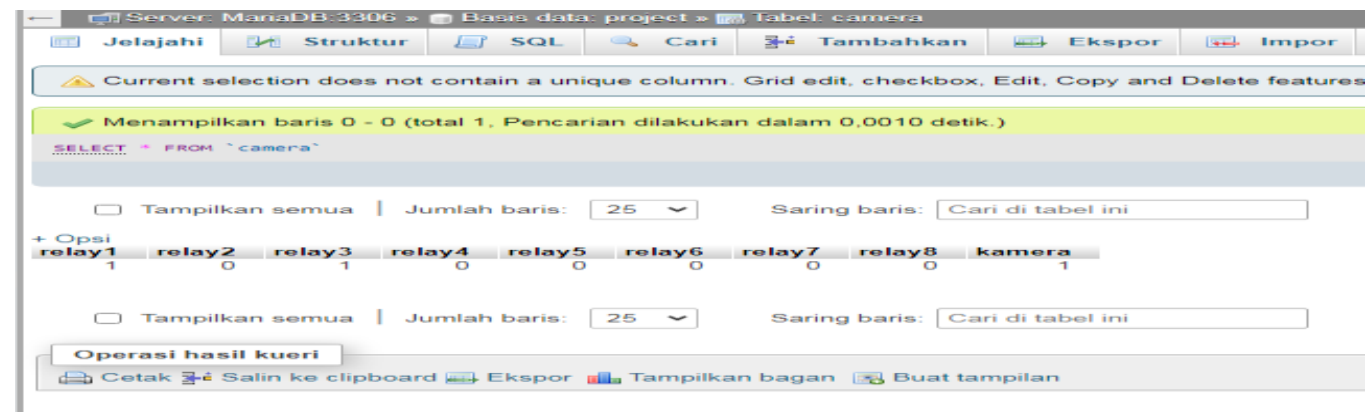

Gambar 19. Hasil Input Pada Database

Maka Hasilnya lampu akan menyala ketika nilai database pada angka 1 seperti pada gambar relay 1 di atas makan lampu teras akan menyala

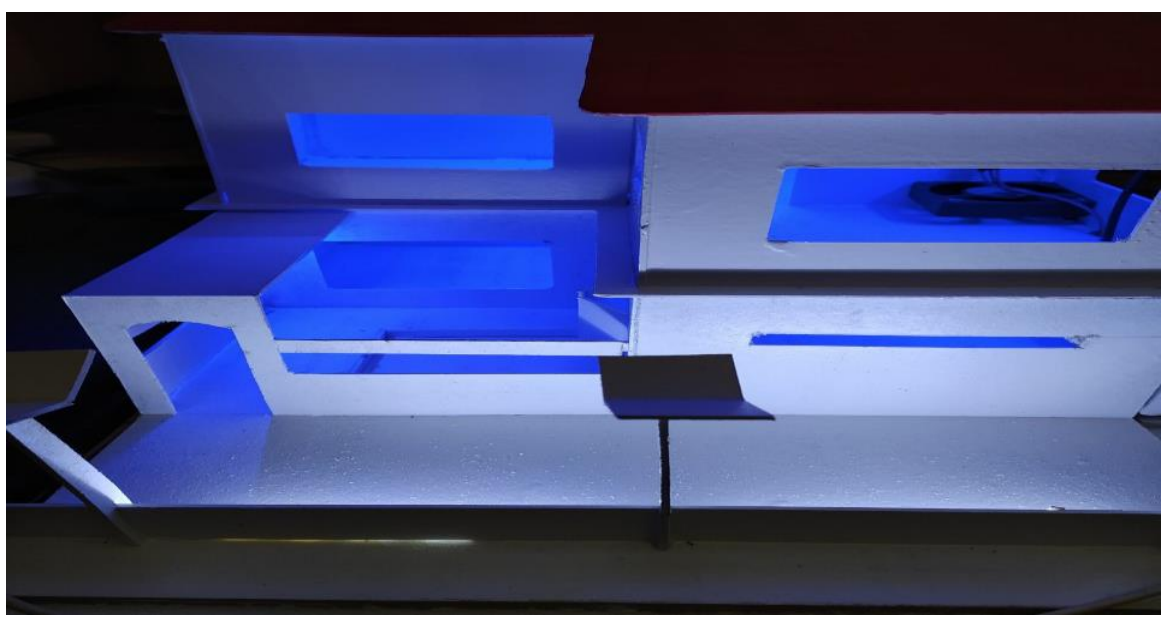

Gambar 20. Relay 1 menyalakan lampu teras

\subsection{Implementasi Sensor suhu (DHT 22)}

Untuk mengetahui suhu pada ruangan otomatis mengunakan sensor model DHT 22 karena sensor terkalibrasi cukup akurat .pada penelitian ini input suhu yang terdapat pada sensor DHT 22.

Sensor DHT 22 akan mengirimkan sebuah nilai pada database yang mana akan di tampilkan pada web secara realtime dan berikut adalah tampilan dari database yang secara otomatis akan di kirim dan di simpan pada database dalam gambar berikut. 


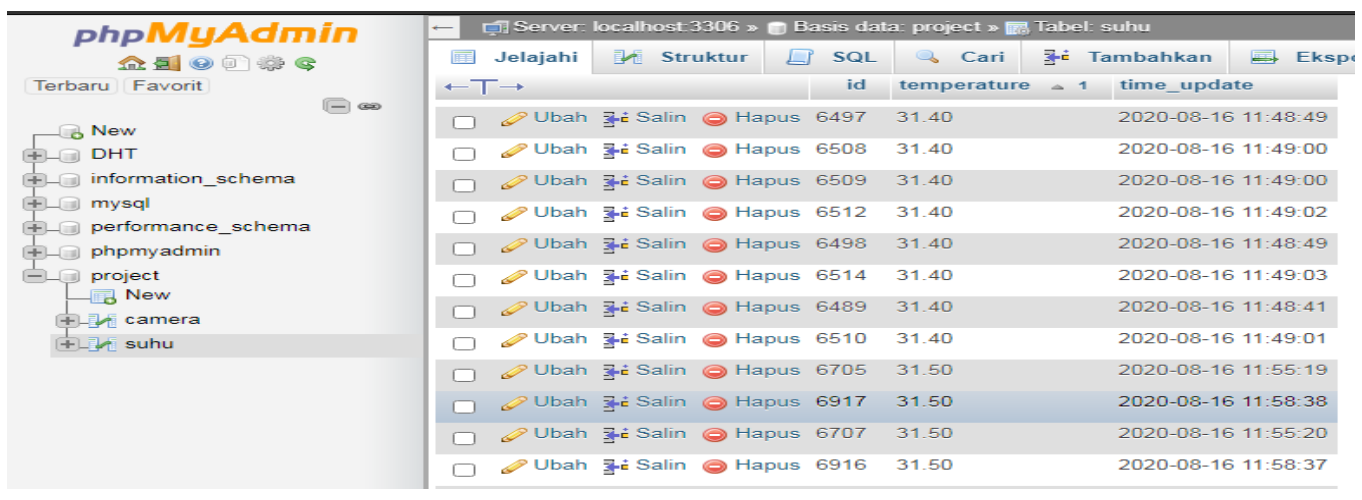

Gambar 21. database sensor suhu DHT 22

\subsection{Implementasi sensor PIR}

Sensor PIR menjadi input yang di dapat kan melalui gerak tubuh untuk menyalakan lampu, sensor PIR digunakan untuk mendeteksi adanya sinar inframerah. Sensor PIR bersifat pasif artinya sensor tidak memancarkan sinar inflamerah tetapi hanya bisa menerima sinar inframerah. Pada saat penguna saat ingin ke kamar mandi akan membuat gerakan yang kemudian sensor akan membandingkan pancaran sinar inframerah . jadi jika ada suatu pergerakan maka sensor PIR akan mendeteksi ada nya gerakan tubuh dan lampu akan menyala secara otomatis seperti pada gambar berikut.

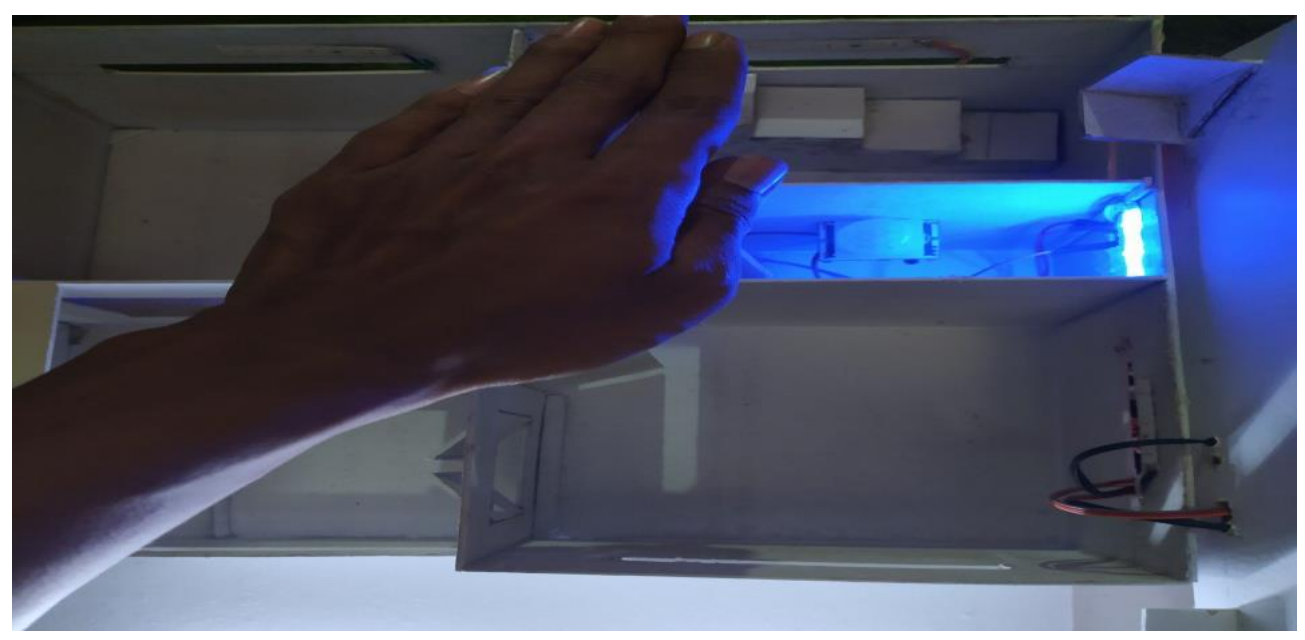

\section{Gambar 23. sensor PIR Menditeksi Gerakan}

\subsubsection{Implementasi Webcam}

Webcam adalah periferal berupa kamera sebagai pengambil citra atau gambar yang di kendalikan oleh sebuah komputer atau oleh sebuah sebuah jaringan. Webcam di gunakan untuk menampilkan sebuah kondisi rumah yang mana akan di tampilkan secara streaming ke web control seperti pada gambar berikut ini. 


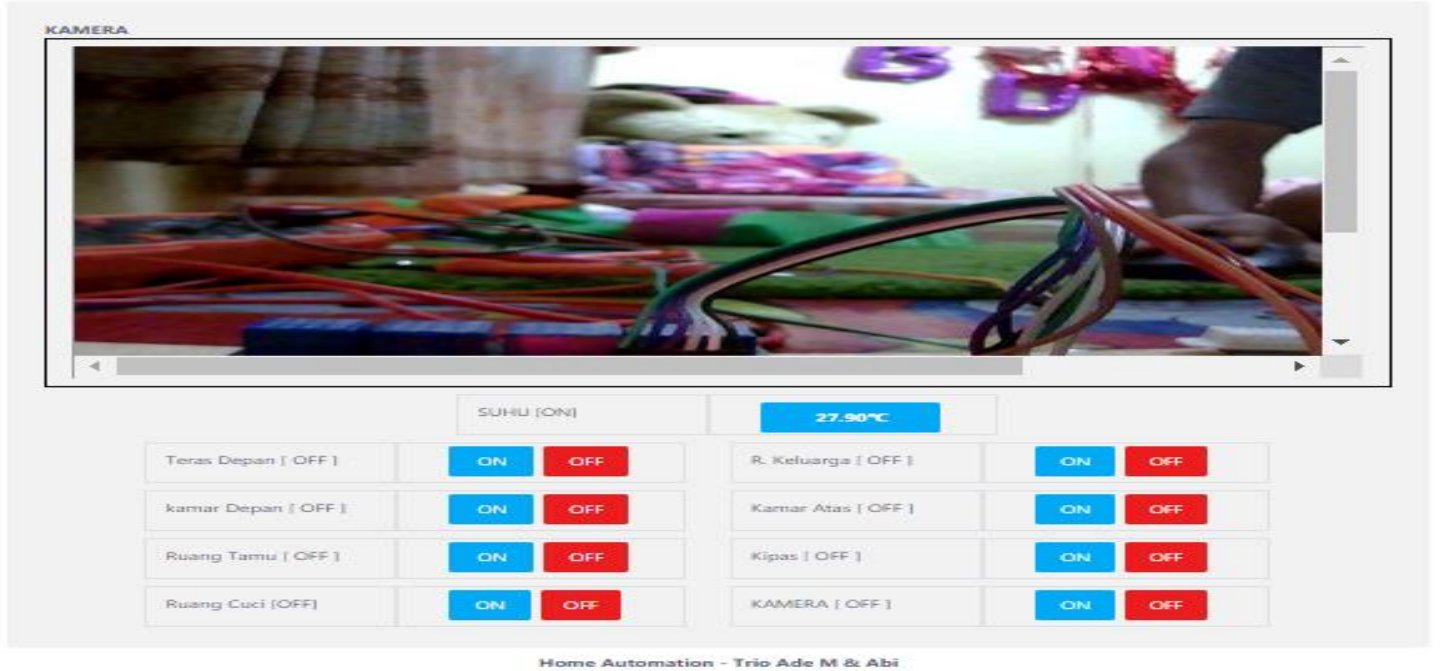

Gambar 23. Streaming webcam

\subsubsection{Gambaran Rangkain Home Automation}

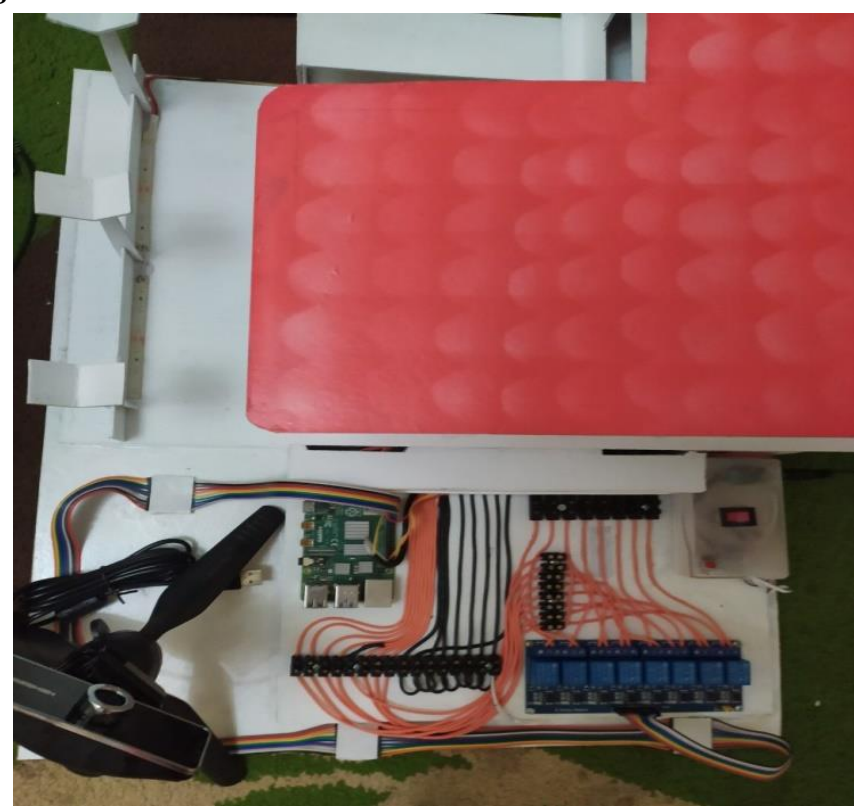

Gambar 24. Prototype Home Automation

Gambar di atas merupan prototype dari keseluruhan dari Home Automation sensor, microcontroller, relay, lampu dan jalur rangkaian kelistrikan yang di kendalikan oleh raspberry yang akan di kendalikan oleh user melalui sebuah jaringan dengan perantara antarmuka web. 


\section{KESIMPULAN DAN SARAN}

\subsection{Kesimpulan}

Dari hasil penelitian Home automation pada raspberry pi 4 dapat di simpulkan beberapa hal antara lain sebagai berikut :

1. Home Automation menggunakan Raspberry pi 4, relay channel 8, sensor suhu atau DHT 22 dan webcam dapat berfungsi dengan baik. Sehingga dapat di kendalikan kapan saja oleh user.

2. Berhasil membangun software untuk Interface web dan terkoneksi dengan raspberry pi 4 .

3. Jaringan internet yang di gunakan sangat berpengaruh terhadap kecepatan respon dari alat yang di buat ini karena semakin kuat sinyal jaringan maka waktu tangkap atau delay akan lebih cepat.

4. System Home Automation juga di rancang dengan optimal sehingga tidak mengunakan listrik secara berlebihan dan bisa menghemat pengunaaan listrik.

\subsection{Saran}

Pada penelitian ini peneliti menyadari bahwa masih jauh dari kata sempurna untuk Home automation ini untuk itu peneliti berharap pada peneliti selanjutnya dapat memperbaiki dan mengembangkan Home automation ini lebih baik dan lebih sempurna. Ada pun saran dari penulis untuk penelitian selanjutnya adalah sebagai berikut

1. Koneksi harus stabil mengunkan dan mengontrol Home automation.

2. Alat ini masih bisa di kembangkan lagi dari sisi hardware dan sisi software baik dari keamanan maupun dari sisi User interfacennya.

3. System dapat di kembangkan kedalam versi android.

\section{DAFTAR PUSTAKA}

[1] Ignatius Prima Haryo Prabowo, Saptadi Nugroho, Darmawan Utomo, 2014, "Penggunaan Raspberry Pi Sebagai Web Server Pada Rumah Untuk Sistem Pengendalia Lampu Jarak Jauh dan Pemantauan Suhu",Jurnal Ilmiah Elektroteknika, Vol. 13. No. 1.111-124

[2] Anggi dan Rummi M.T. 2015, Perancangan Sistem Monitoring Keamanan dalam Ruangan menggunakan Raspberry Pi.

[3] I Nyoman, Yohanes \& Mustakhim,Thamrin. 2015, Home Automation System Berbasis Raspberry Pi dan Web.

[4] Palittin, I. 2015. Rancang Bangun Alat Pengukur Suhu Menggunakan Sensor LM35 dan Mikrokontroler Arduino Uno. Magistra: Jurnal Keguruan dan Ilmu Pendidikan, 2(3),255-262. https://doi.org/10.35724/magistra.v2i3.379

[5] Saleh dan Haryanti, Munnik. 2017. Rancang Bangun Sistem Keamanan Rumah Menggunakan Relay, Jakarta.

[6] Egrit Nurcahyo, dkk. 2015. Sistem Pemantauan Ruangan Dengan Server Raspberry Pi.

[7] Wardana, Endra. 2016. Perancangan dan Implementasi Sistem Monitoring Kamera Berbasis Raspberry Pi 2 Model B (Studi Kasus TK Pertiwi Jelok).

[8] Permana, Tauriq. (2016). Sistem Monitoring Menggunakan Mini PC Raspberry Pi.

[9] Fadhilla, Nur, 2009, Implementasi Perancangan Alat Monitoring Manajemen Dalam Ruangan Berbasis IP. Politeknik Telkom. 